\title{
EFEKTIVITAS SOCIAL MEDIA ADVERTISING: PERAN BRAND FAMILIARITY DAN KONGRUENSI ENDORSER
}

\author{
Sony Kusumasondjaja \\ Fakultas Ekonomi dan Bisnis, Universitas Airlangga Surabaya \\ Jl. Airlangga 4-6, Surabaya 60286 \\ Email: s_kusumasondjaja@yahoo.com
}

\begin{abstract}
Abstrak
Penelitian ini bertujuan untuk menguji pengaruh brand familiarity dan kongruensi citra endorser dengan produk yang diiklankan terhadap respon konsumen pada social media advertising di Twitter. Hasil menunjukkan bahwa social media advertising produk merek dikenal dan di-endorse selebriti dengan kongruensi citra yang tinggi berpengaruh pada terciptanya keyakinan konsumen yang tinggi, sikap lebih positif dan niat beli lebih besar daripada social media advertising lainnya. Menariknya, pada produk dengan merek tidak dikenal, tidak ada perbedaan respon konsumen antara iklan yang di-endorse selebriti dengan kongruensi tinggi atau rendah.
\end{abstract}

Kata Kunci: Brand Familiarity, Citra, Iklan, Kongruensi Endorser, Media Sosial

\begin{abstract}
This study examined the impact of brand familiarity and endorsers' congruence with product being advertised on consumer responses to social media advertising in Twitter. Findings suggested that the product with a familiar brand endorsed by celebrity with high image congruence led to greater consumer trust, more positive attitude, and greater purchase intention than any other familiarity-congruence combinations. Interestingly, for unfamiliar brand, there is no significant difference between high and low endorsers congruence.
\end{abstract}

Keywords: Brand Familiarity, Image, Advertising, Endorser Congruency, Social Media

\section{PENDAHULUAN}

Saat ini mengakses situs social media merupakan hal rutin yang seakan tidak terlepaskan dari aktivitas konsumen sehari-hari. Aktivitas konsumen dalam penggunaan situs social media yang terekam dalam berbagai laporan survei dari berbagai institusi riset ternyata cukup mengesankan. Tercatat dalam laporan statistik yang dirilis oleh eMarketer (2012) bahwa di Indonesia, pengguna social media diprediksi mencapai lebih dari 52 juta orang di tahun 2012 dan akan terus meningkat hingga mencapai lebih dari 79 juta orang di tahun 2014.

Business Measurement Intelligence menyatakan bahwa pengguna Facebook di Indonesia hingga bulan Pebruari 2012 mencapai 43 juta akun yang merupakan angka pengguna tertinggi ketiga di dunia setelah Amerika Serikat dan India, sedangkan pengguna Twitter tercatat hingga akhir tahun 2011 sebesar 19,5 juta akun dengan tingkat aktivitas 1,5 juta tweet per hari yang menempatkan Indonesia pada peringkat lima dunia setelah Amerika Serikat, Brazil, Jepang dan Inggris (Djatmiko, 2012).
Popularitas aplikasi social media di kalangan pengguna internet tidak terlepas dari berbagai kelebihan yang ditawarkan. Beberapa penelitian terdahulu menyebutkan bahwa social media memberi pengguna internet kemudahan untuk bersosialisasi (Ellison et al., 2007; Raacke \& Raacke, 2008; Walther et al., 2008), kecepatan memperoleh informasi (Acquisti \& Gross, 2006; Mazer et al., 2007) serta pemenuhan kebutuhan aktualisasi diri (Gangadharbatla, 2008; Valenzuela et al., 2009).

Manfaat-manfaat tersebut dapat dengan mudah diperoleh pengguna internet, terlebih setelah aplikasi social media dapat diakses dari peralatan komunikasi mobile, seperti telepon genggam atau telepon pintar (smart phone). Tingginya tingkat adopsi konsumen pada social media diterjemahkan sebagai peluang oleh pemasar yang lalu memanfaatkan media ini untuk berbagai aktivitas pemasaran, termasuk untuk beriklan.

Kemunculan berbagai iklan di situs jejaring sosial seperti Facebook dan Twitter dengan tampilan dan cara endoserment yang berbeda-beda merupakan indikasi kuat meningkatnya tingkat adopsi media 
sosial sebagai media alternatif penempatan iklan. Ada iklan yang menampilkan merek yang sudah familiar dan dikenal luas oleh konsumen, ada pula yang memajang merek baru yang memang menggunakan media sosial untuk memperoleh kesadaran konsumen (consumer awareness).

Khusus di media Twitter, iklan produk seringkali dilontarkan oleh akun perusahaan penghasil produk. Namun, iklan tersebut lebih sering disajikan dalam bentuk endorsement oleh akun yang populer dan dikenal memiliki banyak follower, yang dikenal sebagai celebtweet, karena coverage-nya yang cenderung lebih luas. Ada akun populer yang memberikan endorsement untuk produk yang relevan dengan aktivitasnya sehari-hari. Namun, ada juga akun po-puler yang memberikan endorsement untuk produk yang tidak relevan dengan aktivitasnya seharihari. Meskipun berbagai macam iklan dan endorsement di social media Twitter sudah banyak digunakan, efek-tivitas social media advertising belum terdukung pe-nelitian empiris (Kaplan \& Haenlein, 2010). Faktor-faktor yang mempengaruhi efektivitas tersebut juga belum banyak dieksplorasi.

Kesenjangan tersebut dijawab dalam penelitian ini melalui pertanyaan penelitian berikut:

1. Apakah terdapat perbedaan keyakinan (trust) dan niat beli konsumen atas produk yang diiklankan melalui media sosial Twitter pada tingkatan brand familiarity yang berbeda (merek yang dikenal dan tidak dikenal konsumen)?

2. Apakah terdapat perbedaan keyakinan (trust) dan niat beli konsumen atas produk yang diiklankan melalui media sosial Twitter pada kongruensi endorser yang berbeda (kesesuaian tinggi dan rendah)?

3. Apakah terdapat efek interaksi antara brand familiarity dan kongruensi endorser pada keyakinan (trust) dan niat beli produk yang diiklankan di media sosial Twitter?

\section{LANDASAN TEORI DAN HIPOTESIS}

\section{Social Media Advertising}

Kaplan \& Haenlein (2010) mendefinisikan social media sebagai layanan aplikasi berbasis internet yang memungkinkan konsumen untuk berbagi pendapat, pemikiran, cara pandang dan pengalaman. Social media mampu memenuhi kebutuhan konsumen atas informasi dengan menawarkan informasi yang faktual, spesifik, berbasis pengalaman dan bersifat non-komersial, yang dapat diperoleh dan diakses melalui sumber-sumber informasi di luar batasan lingkar kehidupan sosial konsumen tersebut (Yoo \& Gretzel, 2011). Social media juga mampu memenuhi kebutuhan konsumen atas aktualisasi diri dengan memberikan kesempatan untuk mendeskripsikan, merekonstruksikan dan menceritakan pengalaman konsumsi mereka melalui media online (Pudliner, 2007; Tussyadiah \& Fesenmaier, 2009; Xiang \& Gretzel, 2010).

Sejak pertama kali diperkenalkan kepada publik, situs-situs social media telah mampu menarik jutaan pengguna internet. Konsumen menjadikan social media sebagai tempat untuk mencurahkan kecintaan dan kebencian mereka pada merek (Muniz \& Schau, 2005; Flight, 2005; Kahney, 2004), untuk mencari dan berbagi informasi (Bambauer-Sachse \& Mangold, 2011; Kusumasondjaja et al., 2012; Muniz \& Schau, 2007) dan untuk menjalin serta melepas hubungan sosial atau pertemanan (Kim et al., 2010). Banyak konsumen menganggap social media sebagai bagian dari kehidupan sehari-hari yang tidak terpisahkan. Sebagian social media memperkuat upaya konsumen mempertahankan jaringan sosial yang tercipta sebelumnya, ada pula yang menawarkan manfaat untuk membantu menghubungkan pengguna dengan orangorang lain yang memiliki kesamaan minat dan aktivitas (Kaplan \& Haenlein, 2010).

Pemasar yang menyadari pergeseran peran social media pada konsumen akhirnya turut memanfaatkan social media sebagai vehicle penyampai informasi pemasaran (Drury, 2008; Hoffman \& Fodor, 2010; Mangold \& Faulds, 2009; Thackeray et al., 2008). Mangold \& Faulds (2009) mendiskusikan pengaruh interaksi antar konsumen di social media pada penyusunan dan eksekusi strategi komunikasi pemasaran terpadu dan menyajikan saran untuk mengadopsi paradigma baru dalam strategi komunikasi perusahaan. Reid et al. (2005) mendukung pendapat tersebut dan menjelaskan peran strategis social media dalam pembentukan customer-based brand equity. Sementara itu, Eyrich et al. (2008) meneliti proses adopsi social media untuk aktivitas hubungan masyarakat (public relation) yang dilakukan oleh perusahaan.

Meski tingginya tingkat adopsi dan pengunaan social media sudah merupakan fenomena tak terbantahkan, literatur di bidang social media masih mengkaji tema-tema dengan cakupan yang cukup terbatas. Kebanyakan penelitian social media berkutat pada pembahasan tentang motivasi pengguna (Ko et al., 2005; Zheng et al., 2009), proses pencarian informasi (Xiang \& Gretzel, 2010), perbedaan gender dan interaksi antar pengguna (McMahan et al., 2009), sikap konsumen terhadap iklan interaktif (Cheng et al., 2009), kredibilitas informasi (Kusumasondjaja et al., 2012) dan kedekatan online (Calder et al., 2009). Studi tentang respon konsumen terhadap social media advertising belum banyak dieksplorasi. 


\section{Brand Familiarity}

Baker et al. (1986) mendefinisikan brand familiarity sebagai konstruk yang berhubungan langsung dengan alokasi waktu yang dihabiskan untuk memproses informasi tentang sebuah merek tertentu, terlepas dari jenis konten informasi yang diproses. Brand familiarity mengacu pada sejauh mana konsumen memiliki kedekatan langsung maupun tidak langsung dengan merek (Alba \& Hutchinson, 1987; Kent \& Allen, 1994). Konsep ini merupakan konstruk multi-dimensi yang berkaitan dengan berbagai pengalaman yang dimiliki konsumen dengan merek.

Sebuah merek dikatakan memiliki kedekatan yang tinggi apabila konsumen mengenal dengan baik (familiar) merek tersebut, sebaliknya sebuah merek dikatakan memiliki kedekatan rendah bila konsumen tidak mengenal dengan baik (unfamiliar) merek tersebut. Tingkat pengenalan merek memiliki implykasi yang sangat berarti bagi konsumen. Misalnya, pada saat berhadapan dengan informasi tentang produk, konsumen cenderung untuk melakukan proses kognitif lebih intensif dan menilai kelayakan strategi iklan untuk merek yang kurang dikenal (Campbell \& Kirmani, 2000; Shiv et al., 1997). Merek yang familiar mendorong konsumen untuk membentuk asosiasi positif sebagai dasar memberikan judgment sebagai produk yang terpercaya (Aaker, 1991; Keller, 1993).

Pengaruh sikap konsumen pada iklan terhadap respon konsumen pada merek juga lebih kuat apabila merek yang diiklankan kurang dikenal oleh konsumen dibandingkan dengan merek yang diiklankan dikenal baik oleh konsumen (Campbel \& Keller, 2003; Machleit et al., 1993; Machleit \& Wilson, 1988). Produk dengan merek yang dikenal baik memiliki keunggulan dalam meraih respon positif dari konsumen berupa perhatian yang lebih intensif maupun pesan iklan yang lebih mudah diingat (Pae et al., 2002). Bahkan, Shapiro et al. (1997) menjelaskan bahwa produk dengan merek yang dikenal baik oleh konsumen akan direspon dengan positif, terlepas dari isi dan presentasi iklan produk tersebut. Dalam konteks belanja online, konsumen cenderung melakukan pembelian online pada toko yang mereknya sudah dikenal (Park \& Stoel, 2005). Untuk merek yang belum dikenal, konsumen bisa memiliki ketertarikan terhadap produk bila informasi produk disampaikan dengan iklan online yang kreatif (Machleit et al. 1993).

\section{Kongruensi Endorser dan Respon Konsumen pada Iklan}

Kongruensi endorser mengacu pada sejauh mana tingkatan kesesuaian citra diri seorang endorser dengan produk yang memasang nama dan wajahnya (Biswas et al., 2006). Seorang endorser dikatakan memiliki kongruensi tinggi apabila endorser tersebut dipersepsikan memiliki kesesuaian (match-up) dengan produk yang diiklankannya. Sebaliknya seorang endorser dikatakan memiliki kongruensi rendah apa-bila endorser tersebut dipersepsikan memiliki kesesuaian yang lemah dengan produk yang diiklankannya. Penelitian terdahulu menemukan bahwa en-dorser yang memiliki kesesuaian tinggi pada produk yang diiklankannya direspon lebih positif oleh kon-sumen (Biswas et al., 2006; Fleck et al., 2012).

Penelitian lain menyimpulkan bahwa endorser yang memiliki kesesuaian tinggi akan membuat konsumen menganggap endorser dan iklannya tersebut lebih terpercaya dan lebih menarik (Kamins \& Gupta, 1994). Riset-riset lain yang dilakukan berdasarkan konsep Match-Up Hypothesis juga menyatakan bahwa endorser yang memiliki kesesuaian yang tinggi mampu mendorong niat beli yang lebih besar daripada iklan dengan endorser yang memiliki kesesuaian rendah (Amos et al., 2009; Fleck et al., 2012).

Dengan demikian dapat dikatakan bahwa kongruensi endorser memiliki peran penting dalam pembentukan respon konsumen atas informasi produk. Informasi produk yang disampaikan oleh endorser yang memiliki latar belakang atau kepakaran yang relevan atau kongruen dengan produk tersebut akan direspon baik oleh konsumen.

\section{Online Trust}

Pada saat aktivitas pemasaran dilakukan pada lingkungan online, kepercayaan (trust) konsumen menjadi faktor yang sangat krusial. Hal ini disebabkan oleh ketidakmampuan konsumen untuk menilai kualitas produk yang akan dibelinya atau yang biasa disebut sebagai information asymmetry. Menurut Gefen (2002), online trust dibentuk oleh tiga elemen penting yaitu integrity, ability, dan benevolence. Dalam konteks online, integrity merupakan kepercayaan konsumen bahwa sebuah institusi atau sumber informasi online akan mampu menyampaikan informasi secara jujur dan dapat terpercaya.

Ability merupakan kepercayaan konsumen bahwa sebuah institusi atau sumber informasi online memiliki kemampuan dan kompetensi untuk menyediakan informasi yang dapat diandalkan tentang produk. Benevolence merupakan kepercayaan konsumen bahwa sebuah institusi atau sumber informasi online mempertimbangkan kepentingan konsumen dan kemaslahatan orang banyak dalam menjalankan aktivitas penyampaian informasi online tersebut.

Penelitian ini membatasi konstruk online trust bukan terhadap produk, melainkan terhadap informasi tentang produk yang disampaikan melalui social media advertising di Twitter. Dalam konteks pertukaran informasi online, Kim et al. (2001) menyata- 
kan bahwa konsumen dapat membentuk kepercayaan, baik terhadap informasi online tentang produk maupun terhadap produk itu sendiri, sebelum, pada saat atau setelah terjadinya sebuah transaksi online. Hal ini berbeda dengan kepercayaan yang dibentuk konsumen dalam lingkungan offline, yang mana kepercayaan dapat terbentuk setelah terjadinya transaksi. Konsumen online dapat membentuk kepercayaan pada sebuah produk atau merek bahkan sebelum konsumsi dilakukan, hanya berdasarkan informasi yang mereka terima tentang produk tersebut.

Berdasarkan uraian di pada kajian pustaka di atas, penelitian ini merumuskan hipotesis penelitian sebagai berikut:

$\boldsymbol{H}_{\boldsymbol{l}}$ : Produk dengan merek dikenal yang diiklankan di media sosial Twitter akan menghasilkan (a) kepercayaan konsumenatas iklan produk tersebut yang lebih besar, (b) sikap konsumen yang lebih positif terhadap produk, dan (c) niat beli yang lebih kuat, daripada produk dengan merek tidak dikenal yang diiklankan di media yang sama.

$\boldsymbol{H}_{2}$ : Produk yang diiklankan di media sosial Twitter dengan endorser yang memiliki kongruensi tinggi akan menghasilkan (a) kepercayaan konsumen yang lebih besar atas informasi iklan produk, (b) sikap konsumen yang lebih positif terhadap produk, dan (c) niat beli yang lebih kuat, daripada produk yang diiklankan di media yang sama dengan endorser berkongruensi rendah.

$\boldsymbol{H}_{3}$ : Produk dengan merek yang dikenal dan pesan iklannya di media sosial Twitter disampaikan oleh endorser dengan kongruensi tinggi akan menghasilkan (a) kepercayaan yang lebih besar, (b) sikap konsumen yang lebih positif, dan (c) niat beli konsumen yang lebih kuat, daripada interaksi lainnya.

$\boldsymbol{H}_{4}$ : Produk dengan merek yang tidak dikenal dan pesan iklannya di media sosial Twitter disampaikan oleh endorser dengan kongruensi rendah akan menghasilkan (a) kepercayaan yang lebih kecil, (b) sikap konsumen yang lebih negatif, dan (c) niat beli konsumen yang lebih lemah, daripada interaksi lainnya.

\section{METODE PENELITIAN}

Penelitian ini menggunakan pendekatan kuantitatif untuk menguji perbedaan kepercayaan (online trust) atas informasi produk di media sosial, sikap dan niat beli konsumen terhadap produk tersebut pada brand familiarity dan kongruensi endorser yang berbeda. Desain eksperimen dirancang dengan mengacu pada metode dan tahapan yang digunakan penelitian terdahulu (Kusumasondjaja et al., 2012).
Pengamatan dilakukan untuk melihat efek utama (main effect) dan efek interaksi brand familiarity dan kongruensi endorser pada variabel terikat.

Fokus dari penelitian ini adalah konsumen dari cohort Generasi Y. Menurut penelitian sebelumnya (Engebretson, 2004; Paul, 2001; Morton, 2002; Noble et al., 2009), Generasi Y adalah kelompok konsumen yang lahir antara tahun 1977 sampai dengan 1994 atau yang berusia 18 hingga 35 tahun pada saat penelitian dilaksanakan. Pemilihan partisipan dari Generasi Y didasarkan pada pertimbangan bahwa konsumen dari Generasi Y akan menjadi early adopter produk-produk berbasis internet (Wolburg \& Pokrywczynski, 2001) termasuk social media. Untuk alasan kemudahan akses dan kendali atas homogenitas partisipan, mahasiswa S-1 Fakultas Ekonomi \& Bisnis Universitas Airlangga dipilih untuk menjadi parti-sipan dalam penelitian ini. Penelitian ini menganggap bahwa respon yang diharapkan dari partisipan merupakan sesuatu yang sangat dekat dengan kehidupan mahasiswa sehari-hari, yaitu perilaku konsumsi social media. Dengan demikian, mengacu pada pendapat dari Yavas (1994) bahwa mahasiswa dapat menjadi subtitusi konsumen dalam riset, studi ini memilih untuk menggunakan mahasiswa sebagai partisipan.

\section{Desain Eksperimental}

Penelitian ini merupakan studi eksperimen dengan dua variabel eksperimen dan tiga variabel terukur. Dua variabel eksperimen tersebut adalah brand familiarity yang dimanipulasi dua tingkat (merek dikenal dan tidak dikenal) dan kongruensi endorser dengan produk yang diiklankan yang dimanipulasi dua tingkat (kesesuaian tinggi dan rendah). Tiga variabel terukur pada studi ini adalah kepercayaan pada informasi produk, sikap pada produk yang diiklankan dan niat beli konsumen.

Desain eksperimen between-subject 2 × 2 factorial design dirancang untuk penelitian ini. Hal ini berarti ada empat kelompok perlakuan yang masingmasing perlu disiapkan stimulinya. Stimuli yang digunakan untuk penelitian ini adalah desain posting seorang selebriti di akun Twitter miliknya yang berisi gambar iklan produk (twitpic) dan teks berupa endorsement. Untuk memutuskan nama selebriti dan merek produk yang digunakan dalam penelitian ini, dilakukan pre-test yang menanyakan celebtweet yang populer di kalangan mahasiswa yang nantinya menjadi sasaran partisipan. Berdasarkan hasil pre-test, diputuskan untuk menggunakan tokoh pemuda Pandji Pragiwaksono (@pandji) dan tokoh kuliner Bondan Winarno (@PakBondan) sebagai endorser, serta menggunakan produk tepung bumbu ayam goreng merek Sasa (merek dikenal) dan merek Yummy (merek fiktif atau tidak dikenal) sebagai nama merek produk yang diteliti. 
Selanjutnya, dirancang empat stimuli dengan kombinasi Bondan-Sasa (kongruensi tinggi, kedekatan tinggi), Bondan-Yummy (kongruensi tinggi, kedekatan rendah), Pandji-Sasa (kongruensi rendah, kedekatan tinggi) dan Pandji-Yummy (kongruensi rendah, kedekatan rendah). Hasil uji cek manipulasi menyatakan bahwa keempat stimuli mampu dipahami sebagaimana yang dimaksudkan.

Ketiga variabel terukur yang digunakan dalam penelitian ini akan diuji menggunakan item-item pertanyaan yang digunakan pada penelitian sebelumnya. Item-item pertanyaan tersebut diukur dengan menggunakan skala Likert 1-5, dengan angka 1 (satu) melambangkan sangat tidak setuju dan angka 5 (lima) melambangkan sangat setuju. Skala pengukuran Bart et al. (2005) digunakan untuk mengukur kepercayaan konsumen terhadap informasi produk di media sosial Twitter. Variabel sikap diukur dengan skala pengukuran yang digunakan Chang (2001) dan untuk variabel niat membeli merek, item pengukuran mengadaptasi item yang digunakan Pascal et al. (2002).

Uji pendahuluan (pre-test) dilakukan dengan melibatkan 30 mahasiswa S-1 Manajemen Fakultas Ekonomi dan Bisnis Universitas Airlangga untuk menetapkan stimuli yang digunakan untuk eksperimen. Mengacu pada rekomendasi Hair et al. (2009), pengumpulan data utama (main study) dilakukan dengan melibatkan 200 mahasiswa dari program studi yang sama. Proses pengumpulan data dilakukan secara random assignment dengan mengumpulkan partisipan di dalam ruang kelas. Agar partisipan menunjukkan kesungguhan dalam menjawab pertanyaan, tiga partisipan memperoleh hadiah yang akan diundi setelah eksperimen selesai dilakukan.

Untuk menguji hipotesis penelitian dan menjawab rumusan masalah, digunakan teknik analisis uji $t(t$-test). Uji ini merupakan pengujian parametrik ratarata dari dua kelompok data, baik untuk kelompok data terkait maupun dua kelompok bebas. Tipe $t$-test yang digunakan adalah independent t-test yang membandingkan dua kelompok rata-rata dari dua sampel yang berbeda (independent). Dalam penelitian ini, perbedaan yang akan diamati adalah perbandingan antara kelompok responden yang memperoleh empat jenis stimuli yang berbeda sebagaimana dijelaskan sebelumnya. Interpretasi untuk independent t-test dilakukan dengan cara membandingkan nilai hitung $t$ terhadap nilai kritisnya. Apabila nilai $t$-hitung lebih besar dari nilai kritis atau nilai $t$-tabel, maka dapat dikatakan bahwa kedua kelompok tersebut terdapat perbedaan yang signifikan.

\section{HASIL DAN PEMBAHASAN}

Untuk menguji kehandalan pertanyaan di kuesioner, digunakan uji validitas dan reliabilitas yaitu dengan melihat nilai loading faktor dan nilai Cron- bach's Alpha dari konstruk yang diteliti. Pengujian dilakukan dengan SPSS 18. Apabila diperoleh nilai loading faktor lebih dari 0,45 ; maka item pertanyaan untuk mengukur suatu konstruk dikatakan valid. Apabila koefisien Cronbach's Alpha yang dihasilkan suatu konstruk lebih besar dari 0,6, maka butir-butir pertanyaan yang digunakan dianggap dapat diandalkan (Hair et al., 2009).

Pengujian validitas konstruk melalui analisis faktor dengan rotasi varimax menunjukkan nilai di atas 0,7 untuk semua item. Mengacu pada rekomendasi Hair et al. (2009), penelitian dengan ukuran sampel di atas 150 orang, faktor loading 0,45 sudah dapat dikatakan baik dan signifikan secara statistik. Pengujian korelasi faktor juga menunjukkan perbedaan signifikan dari nilai 1 (satu) yang mengindikasikan bahwa validitas diskriminan tercapai. Hasil uji reliabilitas alat ukur menunjukkan bahwa semua item pengukuran yang digunakan dalam penelitian ini memiliki kehandalan yang baik. Item pengukuran variabel keyakinan konsumen meraih nilai Cron-bach's Alpha 0,923; sikap konsumen 0,839 dan niat beli konsumen 0,904 . Penjelasan rinci tentang hasil uji reliabilitas dan validitas untuk variabel terukur pada penelitian ini tersaji pada Tabel 1.

Pengujian main effect untuk brand familiarity dilakukan untuk menjawab Hipotesis 1a hingga Hipotesis 1c. Berdasarkan hasil pengujian, main effect kedekatan merek ditemukan signifikan $(F=70,25 ; p<$ $0,01)$. Produk dengan merek dikenal yang diiklankan di media sosial Twitter memperoleh keyakinan konsumen lebih besar $(M=4,36 ; S D=0,49)$ daripada produk dengan merek yang tidak dikenal $(M=3,72$; $S D=0,24)$. Produk dengan merek dikenal yang diiklankan di media sosial Twitter juga menghasilkan sikap konsumen yang lebih positif terhadap produk $(M=4,04 ; S D=0,41)$ daripada produk dengan merek yang tidak dikenal $(M=3,02 ; S D=0,11)$. Akan tetapi, tidak ada perbedaan yang signifikan pada niat beli konsumen atas produk yang diiklankan di media sosial antara merek yang sudah dikenal dan tidak dikenal. Dengan demikian, hipotesis $1 \mathrm{a}$ dan $1 \mathrm{~b}$ terdukung, namun hipotesis 1c tidak terdukung.

Pengujian main effect kongruensi endorser dilakukan untuk menjawab Hipotesis 2a hingga Hipotesis 2c. Hasil pengujian menyatakan bahwa produk yang diiklankan di media sosial menggunakan selebriti yang memiliki kesesuaian citra yang tinggi menimbulkan keyakinan konsumen yang lebih besar $(M=4,19 ; S D=0,39)$ daripada pada produk dengan selebriti yang memiliki kongruensi rendah $(M=$ 0,$385 ; S D=0,21$ ). Produk yang diiklankan di Twitter dengan endorser selebriti berkongruensi citra yang tinggi juga menghasilkan sikap konsumen yang lebih 
positif terhadap produk $(M=4,15 ; S D=0,42)$ daripada produk yang diiklankan di Twitter dengan endorser selebriti berkongruensi citra yang rendah $(M$ $=3,08 ; S D=0,14$ ).

Saat diiklankan melalui media sosial Twitter, produk yang diiklankan menggunakan selebriti dengan kesesuaian tinggi mampu menciptakan niat beli konsumen $(M=3,92 ; S D=0,48)$ yang lebih baik daripada produk yang diiklankan dengan menggunakan selebriti dengan kesesuaian rendah $(M=3,28$; $S D=0,28)$. Dengan demikian, hipotesis $2 \mathrm{a}, 2 \mathrm{~b}$ dan $2 \mathrm{c}$ terdukung.

Pengujian interaction effect memperoleh hasil yang signifikan $(F=0,965 ; p<0,001)$. Apabila produk yang diiklankan di media sosial Twitter adalah produk dengan merek yang dikenal dan pesan iklannya disampaikan oleh selebriti dengan kongruensi tinggi, maka dihasilkan keyakinan $(M=4,44$; $S D=0,41)$ dan niat beli konsumen $(M=4,12 ; S D=$ $0,37)$ pada produk tersebut lebih tinggi daripada kombinasi stimuli lainnya. Sebaliknya, pada produk dengan merek yang tidak dikenal dan pesan iklannya disampaikan oleh selebriti dengan kongruensi rendah, maka dihasilkan keyakinan $(M=3,29 ; S D=0,44)$ dan niat beli konsumen pada produk tersebut $(M=3,11$; $S D=0,46)$ lebih rendah daripada kombinasi stimuli lainnya. Dengan demikian, hipotesis 3 dan 4 terdukung. Menariknya, ditemukan juga bahwa pada produk dengan merek tidak dikenal, tidak terjadi perbedaan signifikan dalam keyakinandan niat beli konsumen baik pesan iklannya disampaikan oleh selebriti dengan kesesuaian tinggi maupun dengan kesesuaian rendah.

Dari hasil pengujian statistik, diketahui bahwa produk dengan merek dikenal yang diiklankan di media sosial Twitter akan menghasilkan kepercayaan konsumenatas iklan produk tersebut yang lebih besar dan sikap konsumen yang lebih positif terhadap produk. Namun, niat beli konsumen atas produk tidak berbeda signifikan antara produk bermerek yang dikenal atau tidak dikenal yang diiklankan di media yang sama. Kemudian, diketahui pula bahwa produk yang diiklankan di media sosial Twitter dengan endorser yang memiliki kongruensi tinggi akan menghasilkan kepercayaan konsumen yang lebih besar atas informasi iklan produk, sikap konsumen yang lebih positif terhadap produk dan niat beli yang lebih kuat daripada produk yang diiklankan di media yang sama dengan endorser berkongruensi rendah.

Hasil pengujian efek interaksi menjelaskan bahwa produk dengan merek yang dikenal dan pesan iklannya di media sosial Twitter disampaikan oleh endorser dengan kongruensi tinggi akan menghasilkan kepercayaan yang lebih besar, sikap konsumen yang lebih positif dan niat beli konsumen yang lebih kuat daripada interaksi lainnya,s edangkan produk dengan merek tidak dikenal dan pesan iklannya di media sosial Twitter disampaikan oleh endorser dengan kongruensi rendah akan menghasilkan kepercayaan yang lebih kecil, sikap konsumen yang lebih negatif dan niat beli konsumen yang lebih lemah daripada interaksi lainnya

Selain hasil di atas, diperoleh juga beberapa temuan menarik. Temuan menarik pertama adalah bahwa respon konsumen pada social media advertising ternyata tidak jauh berbeda dibandingkan dengan reaksi mereka terhadap iklan yang dipasang di media tradisional. Hal ini terlihat dari ditemukannya peran pentingnya kedekatan merek dalam menimbulkan respon konsumen yang lebih positif terhadap produk yang diiklankan yang juga ditemukan dalam beberapa studi terdahulu tentang iklan (Huang et al., 2006).

Temuan menarik kedua adalah brand familiarity memiliki pengaruh lebih besar daripada kongruensi endorser terhadap respon konsumen atas social media advertising. Hal ini dapat dilihat dari temuan bahwa pada saat produk yang diiklankan di media sosial memiliki merek yang tidak dikenal, maka respon konsumen tidak berbeda signifikan antara iklan produknya disampaikan oleh endorser dengan kesesuaian tinggi maupun kesesuaian rendah. Temuan ini berkaitan dengan peran strategis merek sebagai alat pengurang risiko bagi konsumen (Huang et al., 2006). Merek yang sudah dikenal akan memberikan jaminan kualitas produk (Park \& Stoel, 2005). Peran merek menjadi lebih penting pada saat informasi tentang produk disampaikan melalui media sosial Twitter yang mana konsumen penggunanya dihadapkan pada begitu banyak informasi online. Dengan demikian, saat berhadapan dengan social media advertising, konsumen akan memberikan reaksi lebih positif pada produk dengan merek yang sudah dikenal.

\section{KONTRIBUSI PENELITIAN}

Penelitian ini memberikan kontribusi teoritis maupun praktis. Pertama, keberhasilan validasi kerangka konseptual serta jawaban atas rumusan permasalahan yang disajikan dalam penelitian ini akan memberikan pemahaman baru tentang keterkaitan teoritis antara proses kognisi, sikap dan niat beli konsumen atas produk yang diiklankan di social media. Temuan empiris penelitian ini diharapkan mampu memberikan kontribusi pada literatur di bidang kajian periklanan, pemasaran dan perilaku konsumen karena penelitian empiris di bidang social media advertising; terutama dalam konteks Indonesia masih sangat terbatas. Kedua, secara praktis, temuan pada penelitian ini diharapkan mampu memberikan kontribusi manajerial bagi pemasar di Indonesia. 
Kontribusi praktis diharapkan akan sangat berarti mengingat masih terbatasnya penelitian empiris mengenai topik ini. Meskipun social media advertising adalah aplikasi baru di dunia pemasaran, namun perkembangan praktik pemasaran dunia memberikan indikasi bahwa pada beberapa masa mendatang, aplikasi social media advertising akan banyak diadopsi oleh banyak perusahaan di seluruh dunia, termasuk Indonesia. Bukti empiris tentang efektivitas strategi social media advertising diharapkan dapat membuat pemasar di Indonesia mengalihkan alokasi anggaran komunikasi pemasaran dari media massa berbayar yang membutuhkan dana besar, seperti TV atau media cetak, pada berbagai vehicle social media yang relatif lebih murah dan lebih tersegmen.

\section{DAFTAR REFERENSI}

Aaker, D. A. 1991. Managing Brand Equity. New York: The Free Press.

Acquisti, A. \& Gross, R. 2006. Imagined Communities: Awareness, Information Sharing, and Privacy on the Facebook. Privacy Enhancing Technologies Lecture Notes in Computer Science, 4258: 36-58.

Alba, J. W. \& Hutchinson, J.W. 1987. Dimensions of Consumer Expertise. Journal of Consumer Research, 13(4): 411-454.

Amos, C., Holmes, G., \& Strutton, D. 2008. Exploring the Relationship between Celebrity Endorser Effects and Advertising Effectiveness. International Journal of Advertising, 27(2): 209-234.

Baker, W., Hutchinson, J. W., Moore, D., \& Nedungadi, P. 1986. Brand Familiarity and Advertising: Effects on the Evoked Set and Brand Preference. Advances in Consumer Research, 13(1): 637-642.

Bambauer-Sachse, S. \& Mangold, S. 2011. Brand Equity Dilution through Negative Online Wordof-Mouth Communication. Journal of Retailing and Consumer Services, 18(1): 38-45.

Bart, Y., Shankar, V., Sultan, F., \& Urban, G. L. 2005. Are the Drivers and Role of Online Trust the Same for All Web Sites and Consumers? Journal of Marketing, 69(4): 133-152.

Biswas, D., Biswas, A., \& Das, N. 2006. The Differential Effects of Celebrity and Expert Endorsements on Consumer Risk Perceptions: The Role of Consumer Knowledge, Perceived Congruency and Product Technology Orientation. Journal of Advertising, 35(2): 17-31.

Calder, B. J., Malthouse, E. C., \& Schaedel, U. 2009. An Experimental Study of the Relationship between Online Engagement and Advertising Effectiveness. Journal of Interactive Marketing, 23(4): 321-331.
Campbell, M. C. \& Keller, K.L. 2003. Brand Familiarity and Advertising Repetition Effects. Journal of Consumer Research, 30(2): 292-304.

Campbell, M. C. \& Kirmani, A. 2000. Consumers' Use of Persuasion Knowledge: The Effects of Accessibility and Cognitive Capacity on Perceptions of an Influence Agent. Journal of Consumer Research, 15(3): 111-116.

Chang, C. 2001. The Impacts of Emotion Elicited by Print Political Advertising on Candidate Evaluation. Media Psychology, 3(2): 91-118.

Djatmiko, H. E. 2012. Cerdik Memanfaatkan Media Sosial. SWA, XXVIII, Maret(31): 15-28.

Drury, G. 2008. Opinion Piece: Social Media: Should Marketers Engage and How Can It be Done Effectively? Journal of Direct, Data and Digital Marketing Practice, 9(3): 274-277.

Ellison, N. B., Steinfeld, C., \& Lampe, C. 2007. The Benefits of Facebook "Friends": Social Capital and College Students' Use of Online Social Network Sites. Journal of Computer-Mediated Communication, 12(4): 1143-1168.

Marketer. 2012. Men in Asia-Pacific Active on Social Networks. (http://www.emarketer.com/Mobile/ Article.aspx?R=1009041, diakses 5 Juni 2012).

Engebretson, J. 2004. Odd Gen Out. American Demographics, 26(4): 11-12.

Eyrich, N., Padman, M. L., \& Sweetser, K. D. 2008. PR Practicioners' Use of Social Media Tools and Communication Technology. Public Relation Review, 34(4): 412-414.

Fleck, N., Korchia, M., \& Le Roy, I. 2012. Celebrities in Advertising: Looking for Congruence or Likability? Psychology \& Marketing, 29(9): 651 -662 .

Flight, G. 2005. Companies Tap into Consumer Passion. Business 2.0 (October).

Gangadharbatla, H. 2008. Facebook Me: Collective Self-esteem, Need to Belong and Internet Selfefficacy as Predictors of the iGeneration's Attitudes toward Social Networking Sites. Journal of Interactive Advertising, 8(2): 5-15.

Gefen, D. 2002. Customer Loyalty in E-commerce. Journal of the Association for Information Systems, 3(1): 27-51.

Hair, J. F., Black, W. C., Babin, B. J., \& Anderson, R. E. 2009. Multivariate Data Analysis. Upper Saddle River: Prentice Hall.

Hoffman, D. L. \& Fodor, M. 2010. Can You Measure the ROI of Your Social Media Marketing. MIT Sloan Management Review, 52(1): 40-50.

Huang, W. Y., Schrank, H., \& Dubinsky, A. J. 2006. Effect of Brand Name on Consumers' Risk Perceptions of Online Shopping. Journal of Consumer Behaviour, 4(1): 40-50. 
Kahney, L. 2004. iPod Fans Get into the Picture. (http://wired.com/news/mac/0,2125,66077,00.ht ml, diakses 20 Mei 2012).

Kamins, M. A. \& Gupta, K. 1994.Congruence between Spokesperson and Product Type: A Matchup Hypothesis Perspective. Psychology \& Marketing, 11(6): 569-586.

Kaplan, A. M. \& Haenlein, M. 2010. Users of the World, Unite! The Challenges and Opportunities of Social Media. Business Horizons, 53(1): 59 68.

Keller, K. L. 1993. Conceptualizing, Measuring and Managing Customer-based Brand Equity. Journal of Marketing, 57(1): 1-22.

Kent, R. J. \& Allen, C.T. 1994. Competitive Interference Effects in Consumer Memory for Advertising: The Role of Brand Familiarity. Journal of Marketing, 58(3): 97-105.

Kim, D. J., Song, Y. I., Braynov, S. B., \& Rao, H.R. 2005. A Multidimensional Trust Formation Model in B-to-C e-Commerce: A Conceptual Framework and Content Analysis of Academia/ Practitioner Perspectives. Decision Support Systems, 40(2): 143-165.

Kim, W., Jeong, O. R., \& Lee, S. W. 2010. On Social Websites. Information Systems, 36(2): 215-236.

Ko, H., Cho, C. H., \& Roberts, M. S. 2005. Internet Uses and Gratifications: A Structural Equation Model of Interactive Advertising. Journal of Advertising, 34(2): 57-70.

Kusumasondjaja, S., Shanka, T., \& Marchegiani, C. 2012. Credibility of Online Review and Initial Trust: The Role of Reviewer's Identity and Review Valence. Journal of Vacation Marketing, 18(3): 185-196.

Machleit, K. A., Allen, C. T., \& Madden, T. J. 1993. The Mature Brand and Brand Interest: An Alternative Consequence of Ad-evoked Affect. Journal of Marketing, 57(4): 72-82.

Machleit, K. A. \& Wilson, R. D. 1988. Emotional Feelings and Attitude toward the Advertisement: The Roles of Brand Familiarity and Repetition. Journal of Advertising, 17(3): 27-35.

Mangold, W. G. \& Faulds, D. J. 2009. Social Media: The New Hybrid Element of the Promotion Mix. Business Horizons, 52(4): 357-365.

Mazer, J. P., Murphy, R. E., \& Simonds, C.J. 2007. I'll See You on "Facebook": The Effects of Computer-mediated Teacher Self-disclosure on Student Motivation, Affective Learning and Classroom Climate. Communication Education, 56(1): 1-17.

Morton, L. P. 2002. Targeting Generation Y. Public Relations Quarterly, 47(2): 46-47.
Muniz, A. M. Jr. \& Schau, H. J. 2005.Religiosity in the Abandoned Apple Newton Brand Community. Journal of Consumer Research, 31(4): 737 -747 .

2007. Vigilante Marketing and Consumercreated Communications. Journal of Advertising, 36(3): 187-202.

Noble, S. M., Haytko, D. L., \& Phillips, J. 2009. What Drives College-age Generation Y Consumers? Journal of Business Research, 62(6): 617-628.

Pae, J. H., Samiee, S., \& Tai, S. 2002. Global Advertising Strategy: The Moderating Role of Brand Familiarity and Execution Style. International Marketing Review, 19(2): 176-189.

Park, J. \& Stoel, L. 2005. Effect of Brand Familiarity, Experience and Information on Online Apparel Purchase. International Journal of Retail \& Distribution Management, 33(2): 148-160.

Pascal, V. J., Sprott, D. E., \& Muehling, D. D. 2002. The Influence of Evoked Nostalgia on Consumers' Responses to Advertising: An Exploratory Study. Journal of Current Issue \& Research in Advertising, 24(1): 39-47.

Paul, P. 2001. Getting inside Gen Y. American Demographics, 23(9): 42-49.

Pudliner, B. A. 2007. Alternative Literature and Tourist Experience: Travel and Tourist Weblogs. Journal of Tourism and Cultural Change, 5(1): 46-59.

Raacke, J. \& Raacke, B. J. 2008. MySpace and Facebook: Applying the Uses and Gratification Theory to Exploring Friend-networking Sites. CyberPsychology \& Behavior, 11(2): 169-174.

Reid, M., Luxton, S., \& Mavondo, F. 2005. The Relationship between Integrated Marketing Communication, Market Orientation, and Brand Orientation. Journal of Advertising, 34(4): 1123.

Shapiro, S., MacInnis, D. J., \& Heckler, S. E. 1997. The Effects on Incidental Ad Exposure on the Formation of Consideration Sets. Journal of Consumer Research, 24(1): 94-104.

Shiv, B., Edell, J. A., \& Payne, J. W. 1997. Factors Affecting the Impact of Negatively and Positively Framed Ad Messages. Journal of Consumer Research, 24(3): 285-294.

Thackeray, R., Neiger, B. L., Hanson, C. L., \& McKenzie, J. F. 2008.Enhancing Promotional Strategies within Social Marketing Programs: Use of Web 2.0 Social Media. Health Promotion Practice, 9(4): 338-343.

Tussyadiah, I. P. \& Fesenmaier, D. R. 2009. Mediating Tourist Experiences: Access to Places via Shared Videos. Annals of Tourism Research, 36 (1): 24-40. 
Valenzuela, S., Park, N., \& Kee, K. F. 2009. Is There Social Capital in a Social Network Site? Facebook Use and College Students' Life Satisfaction, Trust and Participation. Journal of Computer-Mediated Communication, 14(4): 875-901.

Walther, J. B., Van der Heide, B., Kim, S. Y., Westerman, D., \& Tong, S. T. 2008. The Role of Friends' Appearance and Behavior on Evaluations of Individuals on Facebook: Are We Known by the Company We Keep? Human Communication Research, 34(1): 28-49.

Wolburg, J. M. \& Pokrywczynski, J. 2001. A Psychographic Analysis of Generation Y College Students. Journal of Advertising Research, 41 (5): $33-52$.
Xiang, Z. \& Gretzel, U.2010. Role of Social Media in Online Travel Information Search. Tourism Management, 31(2): 179-188.

Yavas, U. 1994. Research Note: Students as Subjects in Advertising and Marketing Research. International Marketing Review, 11(4): 35-43.

Yoo, K. H. \& Gretzel, U. 2011. Creating More Credible and Persuasive Recommender Systems: The Influence of Source Characteristics on Recommender System Evaluations. Recommender Systems Handbook, (Part 3, pp.455-477). Vienna, Austria: Springer.

Zheng, F., Huang, L., \& Dou, W. 2009. Social Factors in User Perceptions and Responses to Advertising in Online Social Networking Communities. Journal of Interactive Advertising, 10(1): 1-13. 